\title{
LEGACY, SUSTAINABILITY AND OLYMPISM: CRAFTING URBAN OUTCOMES AT LONDON 2012
}

\author{
John R. Gold et Margaret M. Gold
}

De Boeck Supérieur | Staps

2014/3 - n 105

pages 23 à 35

ISSN 0247-106X

Article disponible en ligne à l'adresse:

http://www.cairn.info/revue-staps-2014-3-page-23.htm

Pour citer cet article

Gold John R. et Gold Margaret M., « Legacy, sustainability and Olympism: crafting urban outcomes at London 2012 », Staps, $2014 / 3$ n¹05, p. 23-35. DOI : 10.3917/sta.105.0023

Distribution électronique Cairn.info pour De Boeck Supérieur.

(c) De Boeck Supérieur. Tous droits réservés pour tous pays.

La reproduction ou représentation de cet article, notamment par photocopie, n'est autorisée que dans les limites des conditions générales d'utilisation du site ou, le cas échéant, des conditions générales de la licence souscrite par votre établissement. Toute autre reproduction ou représentation, en tout ou partie, sous quelque forme et de quelque manière que ce soit, est interdite sauf accord préalable et écrit de l'éditeur, en dehors des cas prévus par la législation en vigueur en France. II est précisé que son stockage dans une base de données est également interdit. 


\section{Legacy, sustainability and Olympism: crafting urban outcomes at London 2012 \\ Tradition, développement durable et olympisme: transformations urbaines dans le cadre des Jeux de Londres 2012}

JOHN R. GOLD

Department of Social Sciences,

Oxford Brookes University,

Oxford, UK.

E-mail:jrgold@brookes.ac.uk

MARGARET M. GOLD

City of London Business School,

London Metropolitan University,

London, UK

E-mail: m.gold@londonmet.ac.uk
JoHn R. GOLD • Margaret M. GOLD

ABSTRACT: The staging of the Olympic Games has, since the outset, been intended to produce positive and lasting outcomes, but each age has seen the Olympic movement and their appointed host cities recasting the ways in which they have sought to achieve such outcomes in light of their own values and needs. Seen against that background, this paper opens with an historical overview that spans the period since the re-establishment of the Olympics in 1896. It traces the ways in which four notions - memory, regeneration, sustainability and legacy - have progressively emerged as issues that shape the agenda of desired urban outcomes, particularly exploring the evolution of the dynamic, continually evolving but uneasy relationship between sustainability and the overlapping concept of 'legacy'. The latter part of the paper illustrates these ideas with regard to the London 2012 Summer Olympic and Paralympic Games. It analyses the 'One Planet Games' concept, how this was developed for the bid, and how it was subsequently put into practice, commenting particularly on the carbon footprint, the creation of the Olympic Park (as sustainable legacy) and the promotion of sustainable living. The conclusion comments on the continuing challenges encountered in maintaining the visibility of sustainability plans while addressing long-term legacy.

KEYWORDS: Olympics; Olympism; sustainability; legacy; London 2012.

RÉsumé : Dès le départ, l'organisation de Jeux olympiques a été censée avoir des effets positifs et durables, mais, au fil des années, on a vu le mouvement olympique et les villes qui accueillent ces Jeux moduler leurs plans en fonction de leurs propres valeurs et de leurs propres besoins. À partir de cette observation, le présent article jette d'abord un regard d'historien sur la période qui débute à la restauration des Jeux olympiques, en 1896, jusqu'à 2012. Il s'attache à la manière dont quatre notions : mémoire, renouveau, développement durable et tradition ont progressivement émergé comme thèmes prédominants dans la recherche d'un urbanisme meilleur, tout en explorant l'évolution de la relation dynamique, permanente mais aussi difficile entre le « développement durable » et l'omniprésent concept de «tradition ». La dernière partie de l'article donne une illustration de ces idées dans le cadre des Jeux olympiques et paralympiques d'été de Londres 2012. Elle analyse le concept de "Jeux planétaires »; comment ce concept a été présenté dans le dossier de candidature et comment il a été, par la suite, mis en pratique. Elle comprend notamment des commentaires sur la question de l'empreinte de carbone, la création du Parc olympique (en tant qu'héritage à caractère de développement durable) et la promotion d'un mode de vie écologique. La conclusion traite des défis permanents rencontrés lorsqu'il s'agit de conserver un développement durable visible tout en restant sur le long terme fidèle à un héritage traditionnel.

MoTS CLÉS : Jeux olympiques, olympisme, développement durable, tradition, Londres 2012. 


\section{Zusammenfassung: Tradition, nachhaltige Entwicklung und Olympismus: wie wirkt deren Einfluss auf die Stadtentwicklung im Rahmen der Londoner Spiele 2012 ?}

Anfangs ist man davon ausgegangen, dass die Organisation Olympischer Spiele positive und nachhaltige Effekte mit sich bringe. Im Laufe der Zeit war jedoch zu sehen, dass die olympische Bewegung und die Ausrichterstädte die Pläne nach ihren eigenen Werten und Bedürfnissen veränderten. Ausgehend von dieser Beobachtung betrachtet der vorliegende Artikel zunächst aus historischer Sicht die Zeitspanne von der Wiedereinführung der Olympischen Spiele 1892 bis 2012. Er konzentriert sich auf die Art, wie die Begriffe Erinnerung, Wiedererneuerung, Nachhaltigkeit und Tradition nach und nach als dominierende Themen aufgetaucht sind, um eine bessere Stadtentwicklung zu erreichen, wobei die Evolution der dynamischen, dauerhaften, aber auch schwierigen Beziehung zwischen nachhaltiger Entwicklung und dem allgegenwertigen Konzept der Tradition genutzt wird. Der letzte Teil dieses Artikels illustriert diese Ideen im Rahmen der olympischen und Paralympischen Sommerspiele in London 2012. Hier wird das Konzept der „Planetaren Spiele“ analysiert. Es wird gezeigt, wie dieses Konzept bei der Bewerbung präsentiert und später umgesetzt wurde. Es wird besonders die Frage des CO2-Fußabdrucks, die Kreation des Olympiaparks (als Erbe im Sinne nachhaltiger Entwicklung) und die Förderung eines ökologischen Lebensstils kommentiert. In der Konklusion werden die permanenten Herausforderungen behandelt, auf die man stößt, wenn es darum geht, eine sichtbare nachhaltige Entwicklung zu pflegen und dabei langzeitig einem traditionellen Erbe treu zu sein.

SCHLAGWÖRTER: Olympische Spiele, Olympismus, nachhaltige Entwicklung, Tradition, London 2012.

\section{Resumen: Tradición y desarrollo sustentable y Olimpismo : Impacto del urbanismo en el marco de los Juegos de Londres 2012}

$\mathrm{Al}$ inicio de los Juegos Olímpicos, la organización ha estado preocupada de ver los efectos positivos y duraredos, sin embargo al transcurrir los años se ha visto que las ciudades que realizan los juegos deben ajustar sus planes de acuerdo a sus propias necesidades y valores. A partir de esta observación, el presente artículo aborda desde una mirada histórica desde la restauración de los Juegos Olímpicos en 1896 hasta el año 2012. El artículo se centra en cuatro conceptos : la memoria, la renovación, el desarrollo sustentable y la tradición, emergen progresivamente como sujetos predominantes en la investigación de un urbanismo mejor planificado, explorando la evolución de una relación dinámica permanente pero difícil entre el desarrollo sustentable y la presencia de la "tradición”. La última parte del artículo entrega una visión de ideas en el marco de los Juegos Olímpicos y Paralímpicos de Londres 2012. El análisis del concepto de "Juego Planetario", como concepto estuvo presente el dosier de candidatura como también puesto en práctica. Esto comprende los comentarios sobre preguntas relacionados sobre la huella de carbono, la creación de un Parque Olímpico (como herederos de un desarrollo sustentable), y la promoción de un estilo de vida ecológico. La conclusión analiza los desafios actuales de conservar un desarrollo sustentable visible, siendo fieles a la herencia tradicional.

PalabRas Claves: Juegos Olímpicos, Olimpismo, desarrollo sostenible, tradición, Londres 2012.

\section{RIassunto: Tradizione, sviluppo duraturo ed Olimpismo: impatto di questo insieme sull'urbanismo nel quadro dei Giochi di Londra 2012?}

Dall'inizio, l'organizzazione dei Giochi Olimpici è stata censita avere degli effetti positivi e duraturi, ma, sul filo degli anni, si è visto il movimento Olimpico e le città che accolgono questi Giochi modulare i loro piani in funzione dei loro propri valori e bisogni. A partire da questa osservazione, 
il presente articolo getta in un primo tempo uno sguardo alla storia sul periodo che inizia con la restaurazione dei Giochi olimpici, nel 1896, fino al 2012. Ci si collega a quattro nozioni: memoria, rinnovamento, sviluppo duraturo e tradizione sono progressivamente emersi come temi predominanti nella ricerca di un urbanismo migliore, esplorando l'evoluzione della relazione dinamica, permanente ma abbastanza difficile tra lo "sviluppo duraturo" e l'onnipresente concetto di "tradizione". L'ultima parte dell'articolo dà un'illustrazione di queste idee nel quadro dei Giochi Olimpici e Paralimpici estivi di Londra 2012. Essa analizza il concetto di "Giochi Planetari”; come questo progetto è stato presentato nel dossier di candidatura e come è stato, in seguito, messo in pratica. In particolare, comprende dei commenti sulla questione dell'emissione di carbonio, la creazione del Parco Olimpico (in quanto eredità del carattere di sviluppo duraturo) e la promozione di un modo di vita ecologico. La conclusione tratta delle sfide permanenti incontrate quando si tratta di conservare uno sviluppo duraturo visibile restando sul lungo termine fedele all'eredità tradizionale.

Parole Chiave: Giochi Olimpici, Londra 2012, Olimpismo, sviluppo duraturo, tradizione.

\section{INTRODUCTION}

A concern for enduring outcomes lies at the heart of the Olympics in a way that no other sporting or cultural festival can match. Easily the largest and most complex of the genre now routinely termed 'mega-events' (Horne \& Manzenreiter, 2006; Theodoraki, 2007), the Olympic and Paralympic Games have long been seen as vehicles for achieving substantive positive outcomes that are not necessarily linked to the sports field. Understandably, these have changed over time. In each age, the Olympic movement and the cities appointed to host the Games have recast the ways in which they have sought to achieve such outcomes in light of their own values and needs. Early concerns with encouraging sports participation and the promotion of public health, for example, were complemented by later preoccupations with nation building, urban regeneration, place promotion and city marketing. In the process, new and often overlapping notions arose that acted as the conceptual bases for changing approaches and practices.

This paper should be seen against that background. Its principal aim is to explore the tangled relationship between the two concepts sustainability and legacy - that have exerted the greatest influence over the ways in which recent urban outcomes of the Olympics have been viewed and managed. As such, it opens with a historical overview from the re-establishment of the Olympics in 1896 to the present. In doing so, it traces the ways in which four notions - memory, regeneration, sustainability and legacy have progressively emerged as issues that shape the agenda of desired urban outcomes. Thereafter, it focuses on the evolution of the dynamic, continually-evolving but uneasy relationship between 'sustainability' and the alternative concept of 'legacy', especially as illustrated by the experience of the London 2012 Summer Olympic and Paralympic Games. Here, the analysis deals in particular with the idea of the 'One Planet Games', how this was developed for the bid to the International Olympic Committee (IOC) between 2003 to 2005, and how it was subsequently put into practice. The conclusion comments on the continuing challenges encountered in simultaneously implementing sustainability plans while addressing long-term legacy.

\section{IN SEARCH OF OUTCOMES}

An overview of the progress of the Olympics since their reintroduction in 1896 highlights four words that serve to anchor much of the discourse about the urban outcomes of staging the 
Games - memory, regeneration, sustainability and legacy. Each is still a vital and active part of that discourse, although they became influential at different historical moments (see Gold \& Gold, 2011). As re-established in the 1890s, the Olympic Games were founded upon the distant memory of a classical festival that was finally proscribed in $393 \mathrm{AD}$. In Shakespeare's Henry VI Part 3 (Act 2, Scene 3), for example, George, Duke of Clarence entreated his audience:

'And call them pillars that will stand to us; And, if we thrive, promise them such rewards As victors wear at the Olympian games.'

The reference would have been readily understood by audiences at the end of the sixteenth century, for whom the idea of the Olympics as a supreme sporting festival was one of the few reminiscences of Antiquity that had never truly faded away. At different times, various individuals had tried to give expression to social memory by appropriating the title 'Olympic' for sporting and cultural festivals of varying forms and content (Redmond, 1988). Each did so in light of the understandings current in their own times; a characteristic that they shared with the group led by Pierre de Coubertin that re-established the modern Games in the 1890s. Coubertin's group, which became the core of the IOC, broadly subscribed to the principles associated with the idealistic moral philosophy of 'internationalism', which upheld the principle that there could be a community of interests or grounds for collective action shared between the peoples of different nations (Geyer \& Paulmann, 2001). Proceeding on this basis, they romantically conceived the ancient Games as a democratic and pan-artistic panegyris, or a cultural gathering of all the world's people, thereby conceptualising a festival as being based on the twin pillars of 'sport' and 'culture'. In addition, because they saw the Games as part of the general heritage of Western culture rather than belonging to the modern-day Greek nation, they felt that the latter had no proprietorial claim over the Olympics. The Games were therefore free to be allocated to cities throughout the world that were deemed suitable to stage them. At a stroke, too, the relationship between the Olympic movement and its host cities became a central factor that shapes every Games.

It is important to note that, from the outset, the nascent IOC emphasised that there should be positive outcomes from the Olympics, but these were primarily seen in terms of the prestige of staging the Games and the inspiring influence of the Games and its ideals on the host society. The impact on the city as such was something of a sideshow. Early Games, in any case, used existing or temporary facilities. Even when the growing size of the Games prompted the construction of huge new sporting complexes, as with the Reichssportfeld for Berlin 1936, there was actually surprisingly little impact on the city beyond.

Things changed dramatically after the ending of the period of austerity that followed the Second World War. Games organizers from Rome 1960 onwards added progressively greater elements of urban development alongside the sporting and cultural dimensions of the Olympic festivals, particularly in the sense of a real regeneration. As such, the Games became increasingly conceived as an opportunity to remake the physical fabric of targeted areas within the city or to renew basic infrastructure. In doing so, an implicit and arguably somewhat Faustian bargain emerged between the Olympic movement and the host cities. The former, in the shape of the governing IOC, recognised that the host city needed positive outcomes as compensation for the costs of staging an increasingly bloated event - itself equivalent to simultaneously hosting 26 world championships - plus the Paralympic Games and the Cultural Olympiad. It was also sensitive to accusations about gigantism (DaCosta, 2002, 69-90). Nevertheless, the IOC looked askance at the growing extent to which host cities were attaching general exercises in urban development to the Games - a trend that reached its apogee at 
Barcelona 1992, where the organizers invested only 17 per cent of the funds earmarked for the Games on the sporting events and venues as against 83 per cent spent on urban projects perceived to be beneficial to the city. This, it was felt, was tainted by an opportunism that deflected from the Games (Monclús, 2003).

It was therefore highly opportune that two new agendas gradually emerged during the next decade that boosted the IOC's negotiating position vis-à-vis the host cities. The first was environmentalism as mediated through ideas of sustainability. Concerns about the environment had long arisen over the Winter Games' impact on what were often fragile mountain environments; concerns manifested as early as at Lake Placid 1932 (Essex, 2011, 61). The Summer Games too had witnessed criticism of environmental impact, as, for example, with the destruction of important heritage sites at Seoul 1988 (Kim \& Choe, 1997). Driven partly by criticism and partly by the idealism that remains a potent force in the Olympic movement, the 1990s saw a variety of initiatives designed to move environment into a central place within the Olympic movement's core philosophy.

In doing so the IOC was influenced by notions of sustainability that were popularised by the World Commission on Environment and Development (WCED), a body set up by the United Nations in 1983 and chaired by Gro Harlem Brundtland. The so-called Brundtland Report defined sustainable development as: 'development that meets the needs of the present without compromising the ability of future generations to meet their own needs' (WCED, 1987, 43). As such, sustainability was conceived as having social, economic and environmental dimensions which, by implication, necessitated political will to ensure that development did not disadvantage the poor. While the report highlighted issues affecting the developing world, links were made with cities in the developed world as a result of the 'global reach' of their consumption of resources and energy. The overriding message was that society required the 'promotion of values' that would encourage consumption within the 'bounds of the ecologically possible' (ibid., 241, 44). To this end, the Commission aimed to 'raise understanding' and 'commitment to action of individuals, voluntary organizations, businesses, institutes, and governments' (ibid., 4). The subsequent Conference on Environment and Development (the Rio 'Earth Summit') in 1992 encouraged governments and agencies to develop an Agenda for the $21^{\text {st }}$ century (Agenda 21) to address issues including poverty, health, biodiversity, energy, emissions and pollution.

The Olympic movement's response was swift. The Olympic Charter was amended by the addition of the issue of 'environment' in 1991, with a fuller version including 'sustainable development' appearing in 1996. In doing so, 'environment' was adopted as the third pillar of Olympism besides sport and culture. Principles derived from the 1992 Rio Earth Summit also found resonant echoes in the dealings between the IOC and the host cities. In 1994, future candidate cities had to show how their proposals addressed the goal of sustainability, with the IOC's own Agenda 21 document introduced in 1999. By then, the Sydney hosts were looking to create 'Green Games', with an Olympic Park at Homebush Bay much praised at the time although rather less since - for its environmentalist credentials (Cashman, 2011).

Yet at much the same time, another agenda was developing in the shape of legacy, which would rival and surpass sustainability as the guiding framework for considering urban outcomes. Best understood as being something passed from one generation to the next although not necessarily purposefully (as with a bequest in a will), legacy was always a loosely defined and all-embracing concept. A seminar organized by the IOC in 2002 defined it as having:

'many aspects and dimensions, ranging from the more commonly recognised aspects architecture, urban planning, city marketing, sports infrastructures, economic and tourist development - to others [...] that are less well 
recognised $[\ldots]$ the so called intangible legacies, such as production of ideas and cultural values, intercultural and non-exclusionary experiences [...] popular memory, education, archives, collective effort and voluntarism, new sport practitioners [...] experience and knowhow.' (IOC, 2003)

The permissive looseness of this definition allowed legacy to become a notion that was sufficiently flexible to provide an all-inclusive framework for thinking about urban outcomes; able to embrace with equal facility outcomes that could be tangible and intangible, planned and unplanned, direct and indirect, short- and long-term, and positive and negative (Preuss, 2007; Kaplanidou \& Karadakis, 2010; Smith, 2012). In 2003, legacy too was added to the Olympic Charter. Henceforth, candidate cities needed to show not just that their proposals would have sustainable consequences but also that they would leave a positive legacy. Yet 'legacy' perforce suffers from the disadvantages of most comprehensive notions, especially in terms of being vague, easily manipulated to suit different ideologies and, in the case of the Olympics, to fit into different meta-narratives of urban development. Crucially too, legacy overlaps with sustainability as the two concepts that act as filters for visions for post-Games transformation of urban areas most affected by staging the Games. The tensions between these notions and the ways that these tensions have been resolved are amply demonstrated by the example of London 2012.

\section{FraMing LONDON 2012}

This then was the context for London 2012, one of the first bids to be constructed with the new emphases on legacy and sustainability fully in place. In bidding for the 2012 Games, the London team crafted a multi-stranded narrative that fused economic, socio-cultural and environmental arguments into a powerful and highly persuasive selling message (Evans, 2011). The area chosen for the Olympic Park was the Lower
Valley of the River Lea at Stratford in the east of the city - an area that should have represented prime development land given that it was situated just 3-4 kilometres east of London's international finance centre in the City and 1.5 kilometres north of the mushrooming office districts in the Docklands. Its physical environmental condition, however, had militated against its use. The area had been heavily industrial in the 1950s, with extensive clusters of chemical plant and other noxious industries, scrap metal dealers, the locomotive works at Stratford and extensive tracts of railway land. By the millennium, much of this industry had disappeared, leaving large expanses of polluted land in need of, but unlikely to receive, the considerable sums necessary for its regeneration. To some extent, the resulting impression of a post-industrial wasteland was based on an outsider's view of the area, missing the undoubted complexities of its intimately configured social and economic structure (see Cohen, 2013). No such thinking, however, was apparent; at least not until some years later. Rather, the putative bid team presented the Olympic project as a 'once in a lifetime' opportunity to undertake the necessary land decontamination and environmental improvement of what seemed a tabula rasa. In doing so, a brownfield site near the heart of London set amongst some of the most deprived areas - not just of London but of England as a whole - would be transformed. This message, framed around the notion of a permanent and positive legacy, was crucial in selling the project, with all its implications in terms of public expenditure, to the British government in 2003.

By the time that the necessary candidate file was submitted to the IOC in 2005, London had proposals which addressed the known concerns and preferences of the international body. Legacy was everywhere to the fore, but there was also a fully-fledged sustainability agenda. The bid team worked with two voluntary sector environmental organizations: the internationallyconstituted World Wildlife Fund (WWF); and the smaller UK-based BioRegional, founded in 
1992 as a research and education organization that also promotes the development of economically viable, sustainable products and services (BioRegional, 2013). These two organizations had already developed the notion of a 'One Planet Living Agenda' as a programme to promote sustainable living within the capacity of our single planet - not the three planets required if the world consumed natural resources at the rate of Britons and Europeans or the five planets that a North American lifestyle would require. One Planet Living is framed around ten principles: zero carbon; zero waste; sustainable transport; local and sustainable materials; local sustainable food; sustainable water; natural habitats and wildlife; culture and heritage; equity and fair trade; and health and happiness. WWF and BioRegional wanted to use the excitement of the Olympic Games to get across their environmental message to the wider public in London, the United Kingdom and globally. At the same time, it potentially offered the London bid a distinctive environmental mission statement that would differentiate it both from previous Olympics and from the competing cities for the 2012 Games, while providing a more than cosmetic sustainability agenda.

Once the bid was won, these ten principles were expressed in terms of five themes (climate change; waste; biodiversity; inclusion; health and well-being) and 12 sustainability objectives (carbon; transport and mobility; waste; water; materials; biodiversity and ecology; land, water, noise and air; inclusion; supporting communities; access; employment and business; health and wellbeing). The Commission for Sustainable London 2012 (CSL) was set up as an independent monitoring organization to ensure targets were met - the first time that a system of independent monitoring of key stakeholders had been established for an Olympic project. It had the power to interrogate policy-makers, had access to documents, and produced annual and thematic reports which analysed progress and action against the sustainability principles and targets.
It was also expected to play an advisory role to the Olympic Board. At the same time, the CSL developed its own sustainability legacy goals. These combined environmental considerations (e.g. minimum impact on climate change) with prominent display of social sustainability and community goals, including improvements to housing, skills, health, sustainable lifestyles and disability inclusion.

The principle of having an independent assurance body was important in its own right, but equally it was decided that the CSL itself should be subject to scrutiny at the end of the Games period by consultants appointed for the purpose. Their findings were that the Olympic Delivery Authority (ODA) and the stakeholders judged CSL's contribution as 'significant' in helping to embed sustainability within the governance and strategy of the Olympic project, in stopping sustainability from being ignored, in brokering solutions, and in playing a major role in ensuring that the knowledge and expertise developed by ODA and the London Organizing Committee for the Olympic Games (LOCOG) was captured and shared (CAG, 2013, 56).

Legacy outcomes, the other side of the coin, were expressed in a series of Legacy Promises from the UK Government and from the Mayor of London. The Government (DCMS, 2007) embraced a national perspective, promising legacy in the fields of elite sport and sport participation, transforming East London and the Olympic Park, and showcasing the UK as a "creative, inclusive and welcoming place to live in, visit and for business'. A promise to transform the lives of disabled people was added in 2009. The Mayor of London in 2008 promised a legacy of sport participation for Londoners as well as jobs, business and volunteering opportunities, the transformation of East London, the creation of sustainable communities, and presenting the world with a vision of London that was 'diverse, inclusive, creative and welcoming' (DCMS, 2009, 67-68). The new Coalition government (elected May 2010) modified the national Legacy Promises in December 2010, 
reducing them from ten to four and, notably, removing mentions of the word 'sustainability'. References to economic growth and regeneration now replaced phrases such as 'sustainable living', 'sustainable Games' and 'sustainable communities' (DCMS, 2010).

This did not necessarily mean that sustainability had been removed from the Olympic project. Rather, it illustrated the emergence of the dominant rhetoric of the Games and the fact that regeneration played a much more prominent role in the nation's mind than sustainability by the time the Games arrived, embodying a more pragmatic approach to the project and expressing tangible outcomes in terms of legacy. Sustainability continued to operate at a number of levels. These included: preparing for the Games in a sustainable way; staging the Games as sustainably as possible; creating a sustainable legacy of infrastructure, venues, housing and organizations that operate sustainably; and creating a legacy of sustainability in terms of behaviour and practice. Nevertheless, the cautious terminology and the guarded claims made for the Games in achieving sustainable outcomes do reflect the fact that staging the world's largest mega-event is inherently an unsustainable activity. Part of the justification in environmental terms, therefore, is to leave a legacy of changed attitudes, instances of best practice, and new professional and industry codes of practice that will lead to reduced environmental impact in future projects. Indeed, these outcomes can, in a sense, be seen as offsetting the impact of London 2012. In the words of CSL (2012: 'We therefore cannot call the programme truly sustainable unless the inspirational power of the Games can be used to make a tangible, far reaching difference'.

A number of reports were published around Games' time in 2012 and in 2013 that provided overarching assessments of the London 2012 Olympic and Paralympic Games in terms of sustainability performance in the preparation phases, the staging of the Games and the legacy phase (LOCOG, 2012, 2012a; BioRegional/ WWF, 2012; CSL 2012, 2012a, 2012b, 2013, 2013a). Quantitatively, these amounted to over 800 pages of commentary, analysis, recommendations and evaluations. Qualitatively, they supplied interesting insights by virtue of stemming from three different institutional perspectives. For its part, LOCOG tended to look at sustainability from the perspective of its own responsibility as delivery authority, whereas BioRegional's prime concern was to assess the Games against the principles of its One Planet agenda. CSL sought to evaluate both the main institutions, as well as monitoring the Games experience and legacy plans. All three organizations sought to identify what worked well, what worked in part and areas of failure. Overall, all three agreed that these were the most sustainable Games to date. BioRegional and CSL saw it as their duty to flag up problem areas. None the less, even BioRegional and the WWF, when evaluating the 76 promises made in relation to delivery and legacy of a One Planet Games, estimated that only 12 would fail to be delivered with the majority being achieved (BioRegional/ WWF, 2012, 4).

No claims were ever made that London would be a carbon-neutral Games, but efforts were made to reduce carbon consumption where possible, including reducing embedded carbon during construction. Pioneering work was carried out on estimating the carbon footprint of the Games over the full seven-year span from winning the bid to delivering the Olympic and Paralympic Games; a strategy that contrasted with that adopted for previous Games which had only focussed on the period of the Games and with the emissions associated with the staging of the Games. The carbon footprinting exercise produced a base line figure for carbon consumption against which reductions could be measured. This exercise resulted in the calculation of a global sum of 3.4 million tonnes of $\mathrm{CO}_{2}$ equivalent, which could be attributed to the different phases and components of the preparation and staging of the Games. What is 
showed was that, without action, 50 per cent of the carbon footprint would come from the preparation and construction phases - particularly from the use of concrete and steel. On the basis of such calculations, venue design was revisited and savings made to reduce embodied carbon, particularly in the case of the main stadium and the velodrome. In the case of the latter, an innovative use of materials, natural light and ventilation and water harvesting not only reduced embodied carbon but also contributed to low energy use when in operation.

Overall, a reduction of 400,000 tonnes of carbon equivalent was achieved mainly from areas most directly under the control of the ODA (in the construction phase) and LOCOG in the delivery phase. One area of particular success came from site preparation, where zero waste policy meant that no demolition materials went to landfill and all were reused or recycled. BioRegional and the WWF, however, were critical of the level of reuse, arguing that this was well below what could have been expected (BioRegional/WWF, 2012, 16). Soil decontamination was carried out on site and the soil was reused. Materials were transported primarily by rail (although not as much by water as had been originally planned). Road transport was kept to a minimum. The main areas of failure identified by Bioregional/WWW and the CSL came with respect to deployment of renewable energy, the relationship with commercial sponsors (with difficulties encountered in imposing conditions on companies that were major sponsors of the IOC), supply chain management, energy reduction during the Games, failure to promote links between healthy living, sport, wellbeing and the message of sustainability, and the inefficacy of programmes to promote the benefits of sport and exercise.

Renewable energy and usage of energy by spectators travelling to and from the Games gave rise to particular comment. With regard to the former, the bid document had promised that 20 per cent of energy would be sourced sustainably, in particular from a large wind turbine in the north of the Olympic Park. This project was cancelled and replaced by seven smaller turbines and increased solar energy usage. In addition, the Energy Centre responsible for supplying the Park with cooling, heating and power was criticised for using natural gas and having only one biomass boiler (which used locally sourced woodchips). With regard to carbon offsetting for travel to the Games, LOCOG abandoned the original plans, producing a saving of just £2.7 million. Instead, the mantle was taken up over by BP Target Neutral, an offshoot of British Petroleum. Here, spectators were invited to offset their travel with $\mathrm{BP}$ whether it was a long-haul flight or a London underground journey. By the end of the Games, over half a million journeys had been offset (see BP Target Neutral, 2013 for a description of the methodology employed).

\section{THE CHALLENGE OF LEGACY}

Sustainability, therefore, was an important element in framing the planning and delivery of the Games - as befitted an issue of sufficient concern to be regarded as a pillar of Olympism. Yet, representation of that message to the public was at best sotto voce. To take an example, in the Autumn of 2010, a Government department had funded BioRegional to set up a 'One Planet Experience Centre' to explain the concept involved to the general public, outlining its aims, the progress in achieving them, and, with the help of interactive displays, to show people how to save energy and reduce waste. Yet rather than being displayed at a prominent place in central London or a similar location, it was accommodated in a former showhouse of the Beddington Zero Energy Development (BedZED) at Hackbridge, a small suburb in Surrey. While this might seem a sympathetic environment given that BedZED is a pioneering, environmentally friendly housing development, the site's peripherality to the capital and the fact the local population resisted any external signage meant that it gained very few 
visitors. Equally, during the Games, BioRegional offered an exhibition on the One Planet principle, but this was locked away behind the security screens in the Athletes' Village and was inaccessible to the Games' spectators. Its total of 2000 visitors and 900 pledges to live better unquestionably represented only a small fraction of what it might have achieved in a more accessible location.

By contrast, the emphasis on legacy was ubiquitous. The key element was always likely to be the transition of the Olympic Park to its postGames condition - in itself a potential touchstone of the veracity of the promises made about the entire project.

An Olympic Park Legacy Company (OPLC) had been established in May 2009 to draw up the legacy master plans for the Park (now known as the Queen Elizabeth Olympic Park). This was a public sector not-forprofit company with equal input from the Mayor of London and Government. However, government legislation in November 2011 (the Localism Act) gave mayors the power to establish Development Corporations in areas, within their sole control, that were in need of regeneration. This led to Boris Johnson, who had become London's Mayor in 2008, submitting proposals for the replacement of the OPLC with a mayoral Development Corporation, known as the London Legacy Development Corporation (LLDC). When established in April 2012, it was an organization with more devolved powers than the old OPLC and with responsibility for a somewhat larger area that was no longer coterminous with the narrow confines of the park itself. Its aim (LLDC, 2013) was:

'To promote and deliver physical, social, economic and environmental regeneration of the Olympic Park and its surrounding area, in particular by maximising the legacy of the 2012 Olympic and Paralympic Games, by securing high-quality sustainable development and investment, ensuring the long-term success of the facilities and assets within its direct control and supporting and promoting the aim of convergence.'

While clearly still addressing the agenda of the post-Games transformation of the area, its wider spatial and development remit make it probable that it will be less tied to the Games per se than the OPLC might have been. In addition, the six boroughs of London that hosted the Olympic sports and service venues (the 'host boroughs') will increasingly press their case and interests to be firmly recognised in shaping the Olympic legacy.

According to the Masterplan introduced in 2012, the Queen Elizabeth Olympic Park would become a new district of London (designated E20), that contained housing, commercial and employment areas, and leisure spaces. The already constructed Athletes' Village, renamed the East Village, would be converted into 2818 homes. At the time of writing, the first residents are due to move in imminently. In addition, five new neighbourhoods are to be built in the Park, providing a mixture of accommodation (houses and flats for purchase, part ownership or rent including social housing and affordable housing). District names were chosen through public competition: East Wick, Chobham Manor, Sweetwater, Pudding Mill and Marshgate Wharf. The vision is proffered of an environment that would support and encourage more sustainable living, with appealing artists' impressions of inhabitants engaged in walking, jogging, cycling, growing food in gardens, and taking the air on their balconies. With regard to open space, the northern area will be wilder and offer greater biodiversity, whereas the southern area (around the Olympic Stadium and close to Westfield Shopping Mall) will be leisure - and eventsoriented - intended to become an animated space along the lines of the Tivoli Gardens in Copenhagen or the South Bank in London. 


\section{Discussion And CONCLUSION}

The transition from pre- to post-Games conditions was inevitably going to be challenging. The key bodies responsible for delivering the Games (the ODA and LOCOG) were being wound up and their staff dispersed. Even the CSL was terminated, with no more monitoring after March 2013. These had been institutions with a clear idea of what needed to be delivered for staging the Games that operated according to a timetable that could not be relaxed and with a clear vision of how that should be delivered sustainably. These were replaced by the LLDC, which is working in a very different economic and political environment, and by other public and commercial service providers that have not been central to the Olympic project.

Such changes, with associated uncertainties over finance and political will, complicate the already difficult business of translating visions into reality and delivering the Legacy Promises. The extent to which they will be achieved remains problematic from a variety of standpoints. There is no doubt, for example, that the Olympic Park represents prime development land and will almost certainly be able to dispose of residential properties, especially given the buoyant London housing market. Yet even with the provision of affordable housing, it remains doubtful that many of the new residents will stem from the deprived communities that live adjacent to the Park or even that the proportion of affordable housing will remain sacrosanct in the long-term. Similarly with employment, it remains to be seen how many of those working in the firms and organizations attracted to the Park stem from the host boroughs. If key elements in arguments about legacy were social and economic sustainability, it is difficult to see what mechanisms are likely to support and enhance local community structures or to address deprivation. In their report, BioRegional/WWF (2012) identified seven areas of concern that span the economic, social and environmental dimensions of sustainability. These comprised: the extent of energy consumption in the postGames housing estates (especially the former Athletes' Village); the failure of zero waste policies to be rolled out across East London (recycling; composting waste; converting waste into renewable energy); the absence of an increased market for recyclables; lack of training and job opportunities locally in re-manufacturing; problems in maintaining the local and sustainable supply chain of materials; the failure to make the Lower Lea Valley self-sufficient in water; and the difficulty in creating a distinctly 'green' business hub (i.e. specialising in typically environmentally-friendly activities).

These all relate in some way to the downplaying of the sustainability agenda in the area as a whole and a failure to build on the best practice. The first point about energy consumption in the Athletes' Village, for example, relates to the fact that planning permission for the Village was deliberately rushed through before the tightening of environmental standards in order to encourage developers who might have been put off by stricter regulations. Many of the other points relate to local authority or government unwillingness to consider funding environmentally-motivated initiatives at a time of public financial retrenchment (see also Gold \& Gold, 2009).

Pointing to these problems does not diminish London 2012's genuine success in addressing the technical challenges of staging sustainable Games, where most of the goals have been met. By contrast, little of this success has been communicated to the wider public. In part, this was due to the ineffectiveness of the pedagogic-cum-propaganda initiative, with few people seeming to recognise the One Planet slogan or the concept's relevance. Yet, more significantly, there is no doubt that legacy, sustainability's allied and overlapping counterpart, emerged as the central notion in discourse about postGames transition at London 2012. Legacy could immediately be translated into the visible 
transformation of East London, allied with a sense that a seismic shift had occurred in the geography of London through the investment, accessibility, attention and aura of success that emanated from the Olympic project. Faced with that competition, it was perhaps inevitable that sustainability, with its basis often in less accessible conceptual and ethical arguments, might well take a subsidiary role.

\section{BIBLIOGRAPHY}

BioRegional/WWF (2012). Towards a One Planet Olympics Revisited. London, BioRegional/World Wildlife Fund.

BioRegional/WWF (2013). Our Structure, available online at http://www.bioregional.com/about-us/our-structure/, accessed 10 June 2013.

BP Target Neutral (2013). Olympics 2012 Journey Carbon Footprint Calculator: summary, available online at http://www.bptargetneutral.com/wp-content/ themes/TargetNeutral/images/ERM-methodologystatement.pdf, accessed 28 November 2013.

CAG (2013). Independent Evaluation of the Commission for a Sustainable London 2012 Final Report. London, CAG Consultants.

Cashman, R. (2011). Sydney Olympic Park 2000 to 2010: History and Legacy. Sydney, Walla Walla Press.

Cohen, P. (2013). On the Wrong Side of the Track? East London and the Post Olympics. London, Lawrence \& Wishart.

CSL (2012). Assuring a Legacy - promises, progress and potential. London, Commission for Sustainable London 2012.

CSL (2012a). Breaking the Tape: Pre-Games Review (Annual Review 2011). London, Commission for Sustainable London 2012.

CSL (2012b). London 2012 - from vision to reality: PostGames Report. London, Commission for Sustainable London 2012.

CSL (2013). Making a difference: Post-Games Report. London, Commission for Sustainable London 2012.

CSL (2013a). Beyond 2012 - outcomes. London, Commission for Sustainable London 2012.

DACOSTA, L. (2002). Olympic studies: current intellectual crossroads. Rio de Janeiro, Editora Gama Filho.

DCMS (2007). Our Promise for 2012: How the UK will benefit from the Olympic and Paralympic Games. London, Department of Culture, Media and Sport.
DCMS (2009). London 2012 Olympic and Paralympic Games Impacts and Legacy Framework: Final Report. London, Department of Culture, Media and Sport.

DCMS (2010). Plans for Legacy from the 2012 Olympic and Paralympic Games. London, Department of Culture, Media and Sport.

EsSEX, S.J. (2011). 'The Winter Olympics: driving urban change, 1924-2014', in J.R. Gold \& M.M. Gold (Eds.), Olympic Cities: City Agendas, Planning, and the World's Games, 1896-2016, London, Routledge, 56-79.

Evans, G. (2011). 'London 2012', in J.R. Gold \& M.M. Gold (Eds.) Olympic Cities: City Agendas, Planning, and the World's Games, 1896-2016, London, Routledge, 359-389.

Geyer, M.H. \& Paulmann, J. (2001). The Mechanics of Internationalism: culture, society and politics from the 1840s to the First World War. Oxford, Oxford University Press.

GoLD, J.R. \& GoLD, M.M. (2009). Future indefinite?: London 2012, the spectre of retrenchment and the challenge of Olympic sports legacy. London Journal, 34, 180-197.

GoLD, J.R. \& GoLD, M.M. (2011). 'From A to B: the Summer Olympics, 1896-2008', in J.R. Gold \& M.M. Gold (Eds.), Olympic Cities: City Agendas, Planning, and the World's Games, 1896-2016. London, Routledge, 17-53.

Horne, J. \& Manzenreiter, W. (Eds.) (2006). Sports MegaEvents: Social Scientific Analyses of a Global Phenomenon. Oxford, Blackwell.

IOC (2003). The Legacy of the Olympic Games 1984-2000: Conclusions and Recommendations. Lausanne, International Olympic Committee.

KaplanidoU, K. \& Karadakis, K. (2010). Understanding the legacies of a host Olympic City: The Case of the 2010 Vancouver Olympic Games. Sport Marketing Quarterly, 19, 110-117.

KIM, J. \& ChoE, S.-C. (1997). Seoul: The Making of a Metropolis. Chichester, John Wiley.

LLDC (2013). "What we aim to achieve", available on-line at: http://www.londonlegacy.co.uk/about-us/whatwe-aim-to-achieve, accessed 10 June 2013.

LOCOG (2012). Delivering Change: Pre-Games Sustainability Report. London, London Organising Committee of the Olympic and Paralympic Games.

LOCOG (2012a). London, London Organising Committee of the Olympic and Paralympic Games.

MoncLús, F.J. (2003). The Barcelona model: and an original formula? from "reconstruction" to strategic urban projects (1979-2004). Planning Perspectives, 18, 399-421. 
Preuss, H. (2007). The conceptualization and measurement of mega-sport event legacies. Journal of Sport $\mathcal{E}$ Tourism, 12, 207-227.

Redmond, G. (1988). 'Toward modern revival of the Olympic Games: the various pseudo-Olympics of the nineteenth century', in J.O. Seagrave \& D. Chu (Eds.), The Olympic Games in Transition, Champaign, IL, Human Kinetics, 7-21.

SMith, A. (2009). Theorising the relationship between major sport events and social sustainability. Journal of Sport and Tourism, 14, 109-120.
SMITH, A. (2012). Events and Urban Regeneration: the strategic use of events to revitalize cities. London, Routledge.

Theodoraki, E. (2007) Olympic Event Organization. Oxford, Butterworth-Heinemann.

WCED (World Commission on Environment and Development) (1987). Our Common Future. Oxford, Oxford University Press. 